\title{
Cytotoxicity of activated rat macrophages against syngeneic islet cells is arginine-dependent, correlates with citrulline and nitrite concentrations and is identical to lysis by the nitric oxide donor nitroprusside
}

\author{
K.-D. Kröncke ${ }^{1}$, M.-L. Rodriguez ${ }^{3}$,H.Kolb ${ }^{2}$ and V.Kolb-Bachofen ${ }^{1}$ \\ ${ }^{1}$ Institute of Immunobiology, Department of Medicine \\ ${ }^{2}$ Diabetes Research Institute, Heinrich-Heine-University of Düsseldorf; ${ }^{3}$ Central Research, Department of Biotechnology, \\ Bayer AG, Leverkusen, FRG
}

\begin{abstract}
Summary. Lysis of rat islet cells by syngeneic activated macrophages in vitro can be completely inhibited by the nitric oxide-synthase-inhibitor $\mathrm{N}^{\mathrm{G}}$-methyl-L-arginine. This inhibition can be reversed by an excess of L-arginine. Timedependent lysis of islet cells by activated macrophages is accompanied by increasing concentrations of nitrite and citrulline in the culture medium both of which are measures of nitric oxide formation derived from L-arginine. Lysis of isolated islet cells and disintegration of isolated whole islets is also obtained within $15 \mathrm{~h}$ by culture in the
\end{abstract}

presence of the nitric oxide generating vasodilator sodium nitroprusside. We thus conclude that nitric oxide is extremely toxic for islet cells and that nitric oxide alone and in the absence of other macrophage-generated potentially toxic products can rapidly and completely kill islet cells.

Key words: Activated macrophages, nitric oxide, nitroprusside, cytotoxic activity, islet cells, rat.
In animal models of Type 1 (insulin-dependent) diabetes mellitus macrophages were shown to be the first immunocytes that infiltrate the pancreatic islets of Langerhans in the autoimmune process [1-3]. Administration of silica particles which are selectively toxic for macrophages prevents the onset of insulitis and diabetes $[4,5]$. Activated macrophages have been shown to synthesize nitric oxide (NO) via an L-arginine-dependent pathway [6-8] as effector molecules for killing intra- and extracellular parasites [9-11] and tumour cells in vitro [12-14]. We have shown recently that activated macrophages, when co-cultured with syngeneic rat islet cells at a very low target:effector-cell ratio of $1: 2$, completely lyse islet cells but not hepatocytes or thyrocytes via soluble mediator(s) in vitro $[15,16]$. Lysis could not be inhibited by neutralization of interleukin-1 (IL-1) and tumour necrosis factor-alpha (TNF- $\alpha$ ) by specific antibodies and is dependent on L-arginine [17]. However, in these experiments we could not exclude a co-operative action of various cytotoxic effectors and NO (or a closely related reactive nitrogen-oxide intermediate). By comparison of macrophage-mediated lysis of isolated syngeneic rat islet cells with the lysis mediated by the chemical NO-donor nitroprusside, we now show for the first time, that NO without any synergistic help from other macrophage products can act as an islet toxic effector molecule.

\section{Materials and methods}

\section{Reagents}

Cells were cultured in RPMI 1640 containing $11 \mathrm{mmol} / 1$ glucose supplemented with $6 \times 10^{4} \mathrm{U} / \mathrm{l}$ penicillin, $60 \mathrm{mg} / 1$ streptomycin, $1 \mathrm{mmol} / 1$ sodium pyruvate, $2 \mathrm{mmol} / 1 \mathrm{~L}$-glutamine, $10 \mathrm{ml} / 1$ non-essential amino acids $\times 100,23.8 \mathrm{mmol} / 1 \mathrm{NaHCO}_{3}, 10 \mathrm{mmol} / \mathrm{l} \mathrm{HEPES}$ (Gibco, Heidelberg, FRG) and 10\% heat inactivated fetal calf serum (FCS) (Boehringer Mannheim, Mannheim, FRG). $\mathrm{N}^{\mathrm{G}}$ methyl-L-arginine acetate (L-NMA), sulphanilamide, N-1-naphthylethylendiamine, bovine liver rhodanese $(190 \mathrm{U} / \mathrm{mg}), 8$-bromoguanosine-3':5'-cyclic monophosphate '(8-Br-cGMP), $\mathrm{N}^{2}, 2^{\prime}-\mathrm{O}$ dibutyrylguanosine-3':5'-cyclic monophosphate (dibut-cGMP), $\mathrm{N}^{6}, 2^{\prime}$-O-dibutyryladenosine- $3^{\prime}: 5^{\prime}$-cyclic monophosphate (dibutcAMP), 3-isobutyl-1-methyl-xanthine (IBMX) and the amino acid standards were purchased from Sigma (Deisenhofen, FRG), phenylisothiocyanate, triethylamine and ninhydrin from Pierce (Oud Beijerland, Netherlands), sodium nitroprusside, potassium ferrocyanide, sodium thiosulphate and sodium thiocyanate from Merck (Darmstadt, FRG), acetonitrile and pyridine (HPLC grade) from Promochem (Wesel, FRG) and 8-(4-chlorophenylthio)-guanosine$3^{\prime}: 5^{\prime}$-cyclic monophosphate (8-pCPT-cGMP) from Biolog (Bremen, FRG). Triethylamine was distilled over ninhydrin before use.

\section{Animals}

Male and female Wistar rats $(200 \mathrm{~g})$ from the University breeding facility received a standard diet ("ssniff-R"; Ssniff, Soest, FRG) and tap water ad libitum. 


\section{Macrophage-islet cell co-culture}

Pancreatic islets were harvested by ductual injection of collagenase, submitted to gradient centrifugation and dissociated into a singlecell suspension exactly as described previously [15]. Macrophages were activated in vivo by injection of $500 \mu \mathrm{l}$ heat-inactivated Corynebacterium parvum suspension (Wellcome, Burgwedel, FRG) i.p. 5 days prior to isolation. Macrophages from peritoneal exudate were isolated by adherence to petri dishes pre-coated with FCS and harvested by vigorously rinsing after incubation in $\mathrm{Ca} / \mathrm{Mg}$-free $\mathrm{HBSS}$ at $4^{\circ} \mathrm{C}$ for $5 \mathrm{~min}$. The resulting cell preparations consisted of more than $95 \% \mathrm{ED} 1^{+} \mathrm{ED} 2^{-}$macrophages [16] which have the same phenotype as macrophages in inflamed (but not in normal) islets of pre-diabetic $\mathrm{BB}$ rats [3].

About $4 \times 10^{4}$ islet cells in $200 \mu \mathrm{l}$ were placed in $1.5 \mathrm{ml}$ micro sample tubes (Sarstedt, Nümbrecht-Rommelsdorf, FRG) precoated with culture medium. After $8 \mathrm{~h}$ recovery culture, $8 \times 10^{4}$ peritoneal macrophages with or without L-NMA or L-arginine were carefully added to achieve a total volume of $600 \mu \mathrm{l}$. The cells were allowed to settle and were incubated for the indicated intervals at $37^{\circ} \mathrm{C}$ in a humid atmosphere of $5 \% \mathrm{CO}_{2} / 95 \%$ air. Each experiment was performed two to three times.

\section{Culturing of whole islets}

About 20 whole islets, isolated as described above but not dissociated into single cells, were placed in 96-well flat bottom culture plates (Becton Dickinson GmbH, Heidelberg, FRG). After $1 \mathrm{~h}$, nitroprusside and ferrocyanide, respectively, were added to achieve a total volume of $200 \mu \mathrm{l}$. After $15 \mathrm{~h}$ the islets were investigated by light microscopy.

\section{Electron microscopy}

Fixation, dehydration and embedding of the cells were all carried out in the micro sample tubes in which the cells had been cultured avoiding any transfer and centrifugation steps exactly as described previously [15]. From each co-culture preparation more than $10^{3}$ islet cells from at least three ultra thin sections cut from different planes of the specimen were morphologically analysed by transmission electron microscopy. Cell viability was judged from electron density of cytoplasm together with preservation of intact structures of cellular organelles and continuity of cell membrane. Specimens were always analysed in a numbered and coded fashion; from sections analysed, all cells in the plane of section were counted. Since a cell pellet was embedded, there was no possibility for bias during sectioning.

\section{Determination of nitrite}

Supernatants of cultured cells were deproteinized by ultrafiltration (Ultrafree-MC filter units; Millipore, Eschborn, FRG) and stored at $-80^{\circ}$ E. Nitrite concentrations were determined by diazotization reaction [18]: $30 \mu \mathrm{l}$ supernatant were mixed with $40 \mu \mathrm{l} 1 \%$ sulphanilamid in $4 \mathrm{~mol} / \mathrm{H} \mathrm{HCl}$ and $10 \mu \mathrm{l} 37 \% \mathrm{HCl}$. After $10 \mathrm{~min}, 30 \mu \mathrm{l}$ $1 \% \mathrm{~N}$-1-naphthylethylen-diamine in methanol were added. After mixing the solution, the absorbance at $540 \mathrm{~nm}$ was measured in ProBind assay plates (Becton Dickinson) in a microplate reader (Titertek Multiskan; Labsystems, Helsinki, Finland) using $\mathrm{NaNO}_{2}$ as a standard.

\section{Determination of citrulline}

Citrulline was determined by amino acid pre-column derivatization with phenylisothiocyanate [19] and subsequent HPLC $C_{18}$ on a reverse-phase column $(4.0 \times 125 \mathrm{~mm}$ Super PAC $3 \mu \mathrm{m}$ ODS 2; Pharmacia, Freiburg, FRG). As an internal standard, $50 \mathrm{nmol}$ L-ornithine was added. Coupling buffer $(30 \mu \mathrm{l}$; acetonitrile:pyridine: triethylamine: $\left.\mathrm{H}_{2} \mathrm{O}=10: 5: 2: 3\right)$ was added to $50 \mu \mathrm{l}$ culture supernatant. The solutions were dried in an exsicator by evaporation; the residues were again dissolved in $100 \mu \mathrm{l}$ coupling buffer plus $10 \mu \mathrm{l}$ phenylisothiocyanate. After $10 \mathrm{~min}$ at room temperature, the solutions were again evaporated to dryness. The derivatized amino acids were dissolved in $150 \mu \mathrm{H} \mathrm{H}_{2} \mathrm{O}$ and filtered ( $\mathrm{HV}$ filter, $0.45 \mu \mathrm{m}$, Millipore). Twenty microlitres of the resulting solutions were chromatographed at $38^{\circ} \mathrm{C}$ using the eluents $\mathrm{A}(25 \mathrm{mmol} / \mathrm{l}$ ammonium acetate in $0.05 \%$ phosphoric acid, pH 5.4), B (25 mmol/l ammonium acetate in $0.05 \%$ phosphoric acid, $\mathrm{pH} 5.8$ :acetonitrile $=1: 1$ ) and $\mathrm{C}$ (acetonitrile $: \mathrm{H}_{2} \mathrm{O}=7: 3$ ) at a flow rate of $1.0 \mathrm{ml} / \mathrm{min}$. The column was equilibrated using $90 \%$ eluent $\mathrm{A}$ and $10 \%$ eluent $\mathrm{B}$. The amino acids were separated using the following gradient: after 2 min with $90 \%$ eluent $A$ and $10 \%$ eluent $B$ the composition was changed linearly to $50 \%$ eluent $A$ and $50 \%$ eluent $B$ within 20 min. The effluent was monitored at $254 \mathrm{~nm}$. After each run the column was washed for 3 min with eluent $C$ prior to equilibration with the starting eluent for $12 \mathrm{~min}$. The concentrations of citrulline were calculated comparing the peak areas of citrulline and the internal standard.

\section{Statistical analysis}

Statistical analysis was made using unpaired two-tailed Student's $t$-test.

\section{Results}

\section{Inhibition of macrophage-mediated islet cell lysis} by L-NMA

When islet cells are cultured in $1.5 \mathrm{ml}$ micro sample tubes for $23 \mathrm{~h}$, the cells reassociate to well-preserved pseudoislets (Fig.1A). Co-culturing islet cells with activated macrophages at a target: effector-cell ratio of $1: 2$ leads to complete lysis of beta and non-beta cells (Fig.1B) due to soluble macrophage factor(s) [15]. This lysis is characterized by disrupted plasma membranes concomitant with loss of cytoplasmic content, swollen mitochondria, vesiculated endoplasmic reticulum and chromatin condensation within the nuclei.

$\mathrm{N}^{\mathrm{G}}$-methyl-L-arginine (L-NMA) specificially inhibits NO synthesis by activated macrophages [20,21]. To investigate whether L-NMA inhibits macrophage-mediated islet-cell lysis, activated macrophages and islet cells were co-cultured for $15 \mathrm{~h}$ in the presence of various concentrations of L-NMA in a culture medium containing $1 \mathrm{mmol} / \mathrm{l}$

Fig. 1A-F. Low power electron micrographs of islet cells after $15 \mathrm{~h}$ of culture in the absence $(\mathbf{A}, \mathbf{E}, \mathbf{F})$ and presence $(\mathbf{B}, \mathbf{C}, \mathbf{D})$ of activated macrophages. (A) Islet cell control culture show wellpreserved cells. (B) Islet cells cultured in the presence of activated macrophages result in complete lysis of the target cells. Lysis is inhibited by the addition of $0.1 \mathrm{mmol} / 1 \mathrm{~N}^{\mathrm{G}}$-methyl-L-arginine (L-NMA) (C) and inhibition reversed by an excess (11 mmol/1) of L-arginine (D). Culturing islet cells in the presence of $60 \mathrm{U} / \mathrm{ml}$ rhodanese, $5 \mathrm{mmol} / 1$ thiosulphate and $0.5 \mathrm{mmol} / 1$ nitroprusside resulted in almost complete lysis (E) morphologically indistinguishable from lysis mediated by activated macrophages. As a control, islet cells were cultured in the presence of $60 \mathrm{U} / \mathrm{ml}$ rhodanese, $5 \mathrm{mmol} / \mathrm{l}$ thiosulphate and $2.5 \mathrm{mmol} / \mathrm{l}$ cyanide $(\mathbf{F})$ which resulted in minimal lysis only demonstrating that cyanide released from nitroprusside is not the cytotoxic effector molecule under the conditions used. The arrows point to macrophages. Magnification: $\times 2340$ 

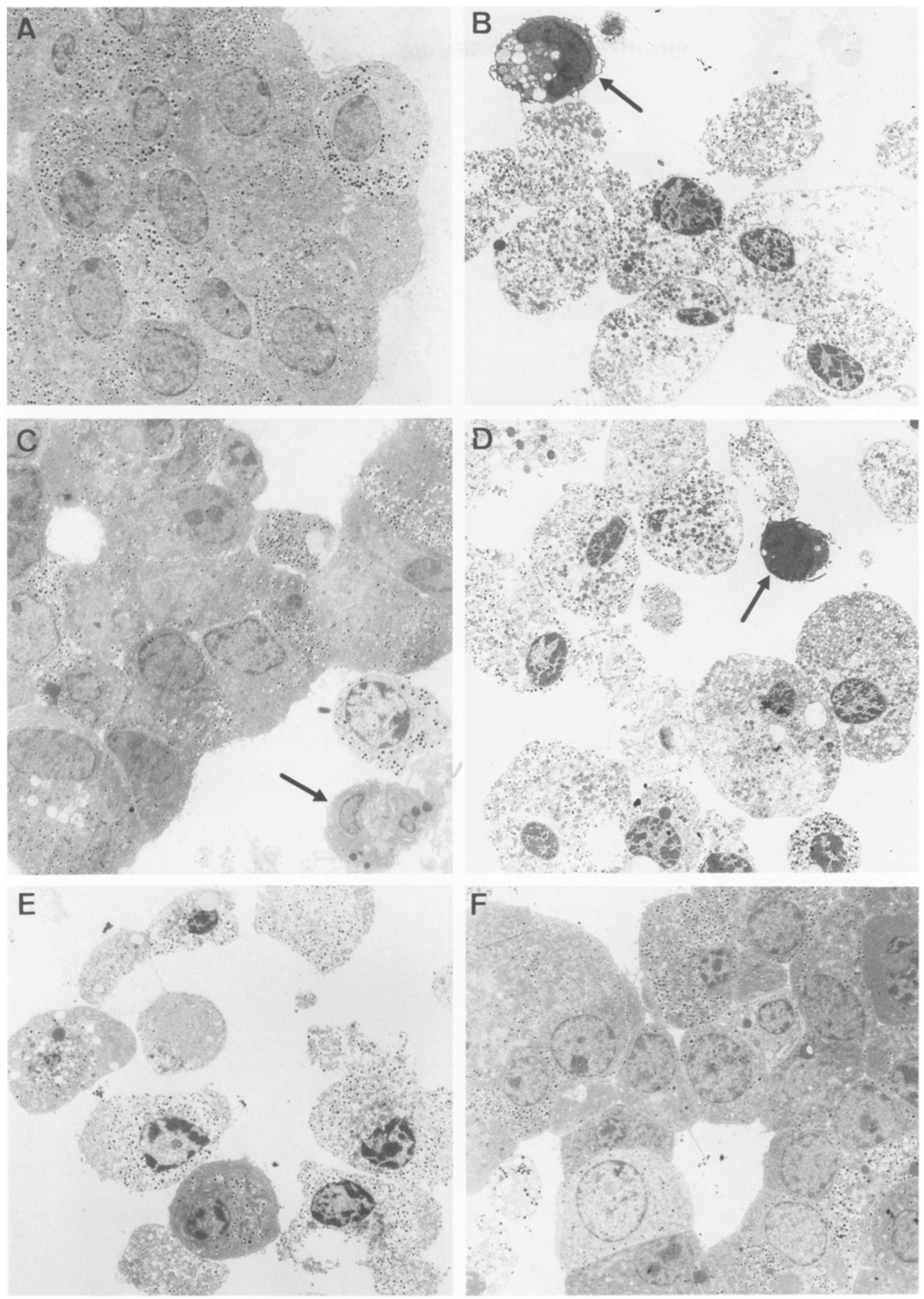


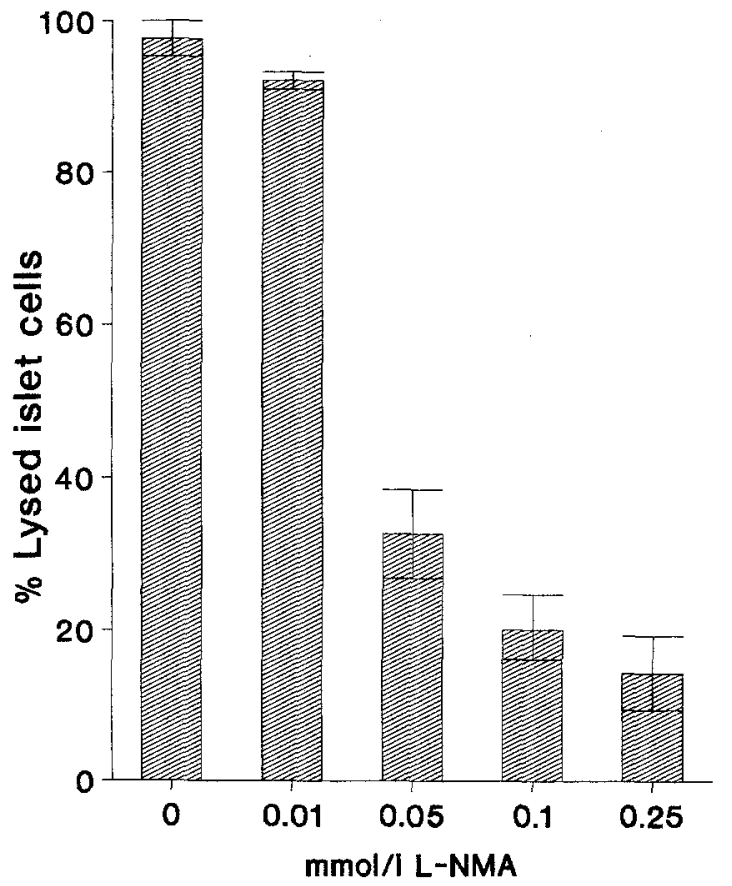

Fig. 2. Concentration-dependent inhibition of macrophage-mediated islet cell lysis by $\mathrm{N}^{\mathrm{G}}$-methyl-L-arginine (L-NMA). Islet cells were co-cultured for $15 \mathrm{~h}$ with activated macrophages in the presence of $0-0.25 \mathrm{mmol} / 1 \mathrm{~L}-\mathrm{NMA}$ in $\mathrm{RPMI} / 10 \%$ fetal calf serum containing $1 \mathrm{mmol} / \mathrm{l} \mathrm{L}$-arginine. Subsequently, the cells were processed for electron microscopy. For each L-NMA concentration at least $10^{3}$ islet cells were examined for lysis by transmission electron microscopy as described in Materials and methods. Values are means \pm SD of three-five individual specimens

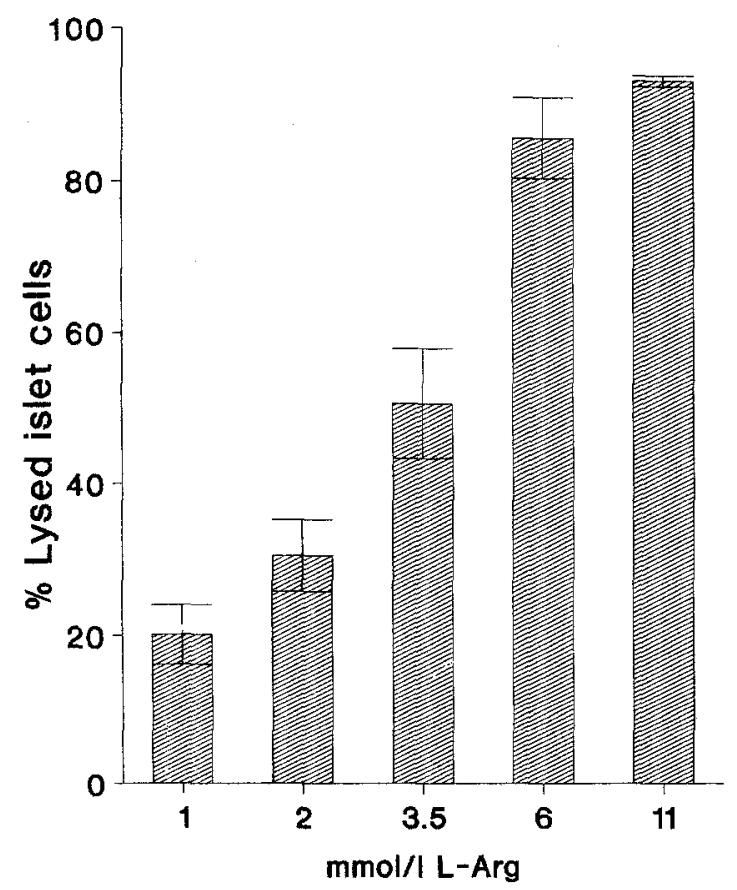

Fig.3. L-arginine dependence of $\mathrm{N}^{G}$-methyl-L-arginine inhibition of the macrophage mediated islet cell lysis. Islet cells were co-cultured for $15 \mathrm{~h}$ with activated macrophages in the presence of $0.1 \mathrm{mmol} / \mathrm{l}$ L-NMA and the indicated concentrations of $\mathrm{L}$-arginine. The cells were processed and examined as described in the legend of Figure 2. Values are means \pm SD of three-five individual specimens
K.-D. Kröncke et al.: Activated macrophages kill islet cells via nitric oxide

L-arginine. As shown in Figure 2, the inhibition of macrophage-mediated islet-cell lysis showed near-linear correlation to the L-NMA-concentration. $0.25 \mathrm{mmol} / \mathrm{l} \mathrm{L}-\mathrm{NMA}$ provided nearly complete protection from macrophagemediated lysis (Fig. 1C). The half-maximal inhibitor-concentration was calculated to be $40 \mu \mathrm{mol} / 1 \mathrm{~L}-\mathrm{NMA}$ which is in the concentration range of half maximal L-NMA-mediated inhibition of NO-production by activated macrophages [22]. Concentrations of up to $0.25 \mathrm{mmol} / \mathrm{l} \mathrm{L-NMA}$ were not toxic for islet cells $(7.9 \pm 1.1 \%$ lysed cells).

\section{Specificity of the inhibitory effect of L-NMA}

To show that L-NMA specifically inhibits the L-argininedependent macrophage-mediated islet-cell lysis, the inhibition experiments with L-NMA were performed in the presence of an excess of L-arginine. Figure 3 shows that inhibition of islet-cell lysis by L-NMA is reversed by L-arginine in a near-linear concentration-dependent manner. Complete restoration of macrophage-mediated lysis of islet cells inhibited by $0.1 \mathrm{mmol} / \mathrm{l} \mathrm{L}-\mathrm{NMA}$ was achieved by 6-11 mmol/l L-arginine. Both, $0.1 \mathrm{mmol} / 1 \mathrm{~L}-\mathrm{NMA}$ and $11 \mathrm{mmol} / \mathrm{l} \mathrm{L}$-arginine, without macrophages added, were not considerably toxic for islet cells $(24.6 \pm 3.5 \%$ lysed cells). Morphologically the observed lysis was indistinguishable from lysis mediated by macrophages without L-NMA and excess L-arginine (Fig. 1D).

\section{Nitrite and citrulline production correlates with macrophage-mediated islet-cell lysis}

The macrophage NO-synthase converts L-arginine into L-citrulline thereby generating $\mathrm{NO}$ which is further oxidized to nitrite and nitrate [6]. To study whether nitrite and citrulline accumulation in the culture medium correlate with islet-cell lysis, time-dependent co-cultures with or without activated or resident macrophages were performed. Lysis of islet cells and nitrite and citrulline concentrations in the supernatants were determined, respectively.

As shown in Figure 4, islet-cell lysis increases with time accompanied by an analogous accumulation of nitrite and citrulline in the culture supernatant. Co-culture of resident macrophages and islet cells for $12 \mathrm{~h}$ does not result in significant target cell lysis nor in measurable concentrations of nitrite and low citrulline concentrations in the culture medium. Also, when culturing isolated islet cells without macrophages for $12 \mathrm{~h}$, no nitrite and only small amounts of citrulline could be detected. Culturing $8 \times 10^{4}$ activated macrophages without islet cells but otherwise under the same conditions results in a similar accumulation of nitrite and citrulline not significantly different from the co-culture experiment (data not shown).

\section{No generating compounds cause lysis of islet cells and islets in vitro}

Sodium nitroprusside (NP; $\left.\mathrm{Na}_{2}\left[\mathrm{Fe}^{\mathrm{II}}(\mathrm{CN})_{5} \mathrm{NO}\right]\right)$ is an inorganic complex that generates NO [23]. To investigate whether islet cells are lysed in vitro by NO derived from 


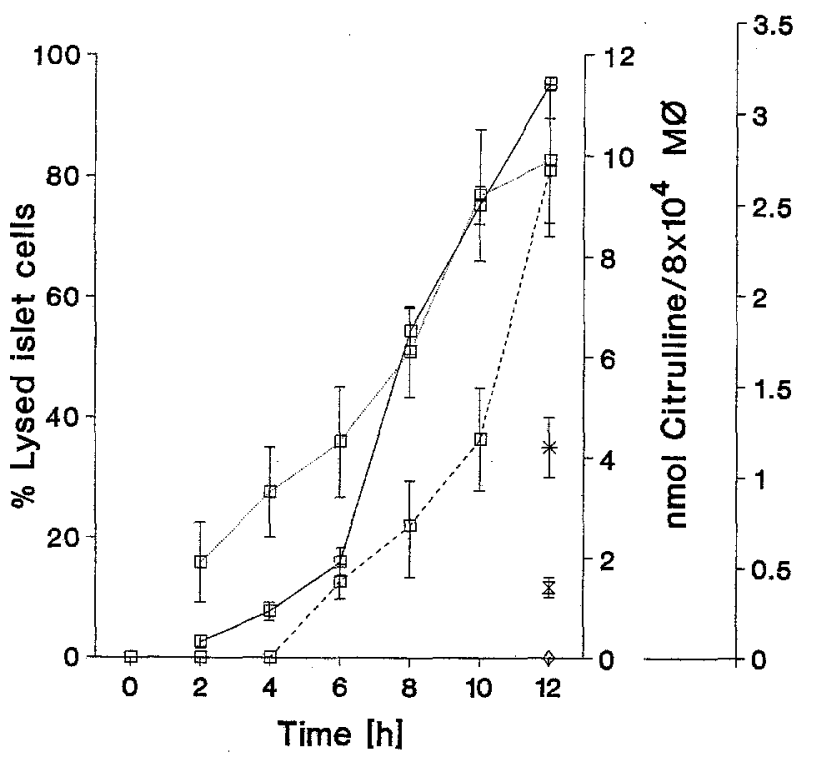

Fig.4. Correlation of time-dependent lysis of islet cells by activated macrophages with concentrations of nitrite and citrulline in the culture medium. $4 \times 10^{4}$ islet cells were cultured in the presence of $8 \times 10^{4}$ activated $(\square)$ or $8 \times 10^{4}$ resident macrophages $(\mathrm{M} \varnothing$; 更, * $\diamond)$, respectively. At the times given, supernatants were removed, deproteinized and stored at $-80^{\circ} \mathrm{C}$. Nitrite concentrations (dashed line, $\diamond$ ) of supernatants were determined spectrophotometrically after diazotization reaction; citrulline concentrations (dotted line, *) were determined by phenylisothiocyanate derivatization and subsequent reverse-phase HPLC. Culture medium background levels of citrulline were subtracted. Islet-cell lysis (continuous line, 更) was quantified as described in the legend of Figure 2. Values are means $\pm \mathrm{SD}$ of three individual specimens

$\mathrm{NP}$, isolated islet cells were cultured for $15 \mathrm{~h}$ in the presence of $0.5 \mathrm{mmol} / 1 \mathrm{NP}$. Potassium ferrocyanide $\left(\mathrm{K}_{4}\left[\mathrm{Fe}^{\mathrm{II}}(\mathrm{CN})_{6}\right]\right)$, a ferrous cyanide complex without nitrosyl ligand, was used as control. In contrast to activated macrophages, NP does not generate oxygen free radicals in the presence or absence of islet cells, as measured by luminol-amplified chemiluminescence (not shown).

While $0.5 \mathrm{mmol} / \mathrm{l}$ ferrocyanide was not toxic for islet cells, $0.5 \mathrm{mmol} / 1 \mathrm{NP}$ caused almost complete lysis of islet cells (Fig.5). Both beta and non-beta cells were equally lysed (data not shown). Morphologically, lysis caused by NP was indistinguishable from lysis caused by activated macrophages (Fig.1E). In addition to the rapid release of NO, NP is known to slowly release cyanide ions in aqueous solution [24]. To rule out the possibility that NP-mediated islet-cell lysis is caused by cyanide, the latter was converted to untoxic thiocyanate by bovine liver rhodanese (thiocyanate: cyanide-sulphurtransferase, $\mathrm{EC}$ 2.8.1.1.) [25] which has been shown to be active at $37^{\circ} \mathrm{C}$ for at least $15 \mathrm{~h}$ in the presence of thiosulphate [26]. Rhodanese $(60 \mathrm{U} / \mathrm{ml})$ and $5 \mathrm{mmol} / \mathrm{l}$ thiosulphate protected islet cells from the toxic effect of $2.5 \mathrm{mmol} / \mathrm{l}$ cyanide but not of $0.5 \mathrm{mmol} / \mathrm{l} \mathrm{NP}$ (Figs. $1 \mathrm{~F}$ and 5). Neither sodium thiosulphate $(5 \mathrm{mmol} / \mathrm{l})$ nor sodium thiocyanate $(2.5 \mathrm{mmol} / \mathrm{l})$, respectively, had toxic effects on islet cells (11.1 $\pm 2.1 \%$ and $2.1 \pm 1.5 \%$ lysed cells, respectively).

To exclude that NP-mediated islet cell toxicity is restricted to the non-physiological state of a dispersed islet

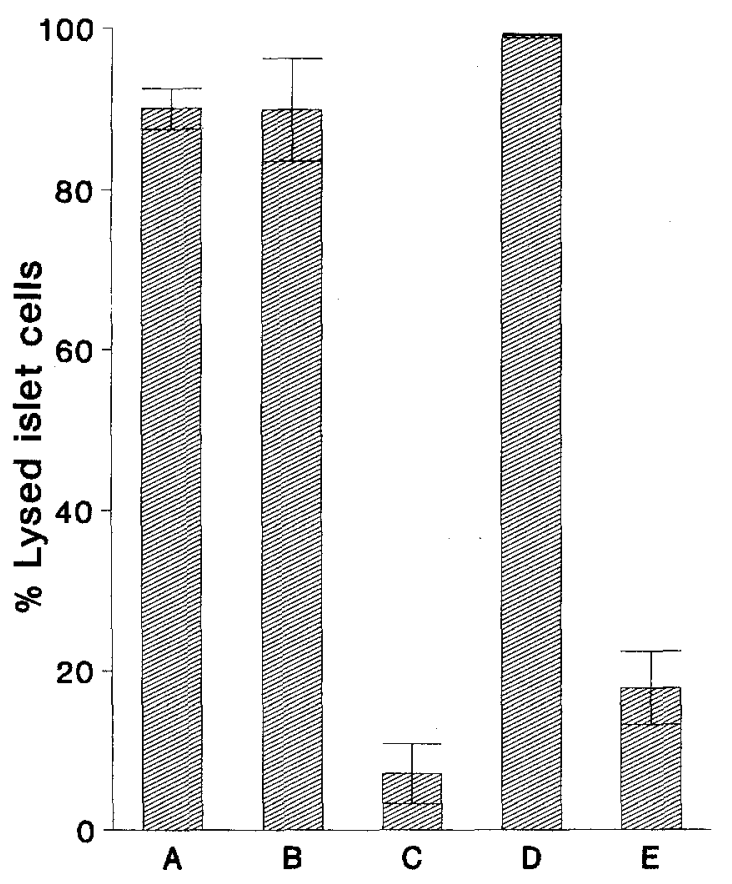

Fig.5. Effect of nitric oxide (NO) generated by the NO donor nitroprusside (NP) on islet cells. Isolated islet cells were incubated for $15 \mathrm{~h}$ with the following compounds: (A) $0.5 \mathrm{mmol} / 1 \mathrm{NP}$; (B) $0.5 \mathrm{mmol} / 1 \mathrm{NP}, 5 \mathrm{mmol} / 1$ thiosulphate, $60 \mathrm{U} / \mathrm{ml}$ rhodanese; (C) $0.5 \mathrm{mmol} / 1$ ferrocyanide; (D) $2.5 \mathrm{mmol} / 1$ cyanide; (E) $2.5 \mathrm{mmol} / 1$ cyanide, $5 \mathrm{mmol} / 1$ thiosulphate, $60 \mathrm{U} / \mathrm{ml}$ rhodanese. Cell lysis was quantified as described in the legend of Figure 2. Values are means \pm of three-four individual specimens

cell suspension and inactive on whole islets, these were also cultured for $15 \mathrm{~h}$ in the presence and absence of $0.5 \mathrm{mmol} / \mathrm{l} \mathrm{NP}$ or $0.5 \mathrm{mmol} / \mathrm{l}$ ferrocyanide. Islet morphology was subsequently evaluated by light microscopy. Islets cultured in the absence or presence of ferrocyanide remained intact with typical round to ovoid shape (Fig. 6A). In contrast, islets cultured in the presence of NP exhibited marked disintegration (Fig. $6 \mathrm{~B}$ ) indicative of extensive lysis.

\section{cGMP-analogues do not induce lysis of islet cells}

$\mathrm{NO}$ in vitro activates the cytosolic guanylate cyclase thus elevating the second messenger cGMP [27]. Indeed, NP and L-arginine have been shown to elevate cGMP-concentrations in isolated rat islets [28, 29]. We therefore tested whether high cGMP levels were sufficient triggers for toxic effects. High concentrations $(1 \mathrm{mmol} / \mathrm{l})$ of cell membrane permeable cGMP-analogues in the presence or absence of the phosphodiesterase inhibitor IBMX were added to islet-cell cultures and lysis was quantitated after $15 \mathrm{~h}$. As shown in Table 1, neither IBMX alone, nor IBMX in the presence of any of the CGMP-analogues, nor the phosphodiesterase stable 8-pCPT-cGMP [30], nor, as a control, a cAMP-analogue in the presence of IBMX caused significant islet-cell lysis. 


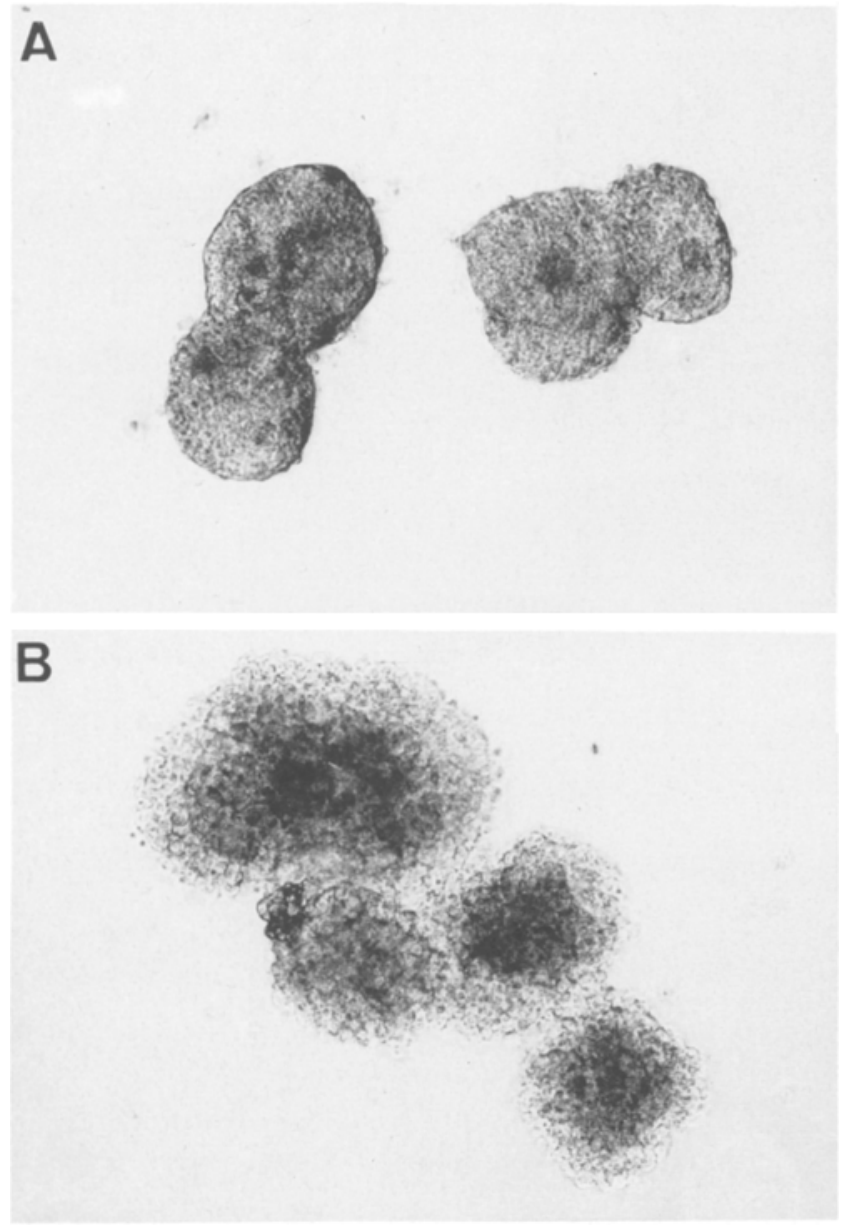

Fig. 6A,B. Effect of nitroprusside on isolated whole islets. Light microscopy of isolated whole islets cultured for $15 \mathrm{~h}$ in the presence of $0.5 \mathrm{mmol} / 1$ ferrocyanide $(\mathbf{A})$ or $0.5 \mathrm{mmol} / 1$ nitroprusside $(\mathbf{B})$. Magnification: $\times 126$

\section{Discussion}

The results presented here show that rat islet cells are susceptible to the toxic effects of NO leading to rapid lysis within $15 \mathrm{~h}$. Firstly, the L-arginine-dependent cytotoxic pathway in activated macrophages is independent from production of reactive oxygen intermediates as has been shown for macrophage cell lines exhibiting either one single or both pathways [31] and by the finding that the L-arginine antagonist L-NMA did inhibit NO but not superoxide production [20]. Although islet cells have been reported to be extremely sensitive towards reactive oxygen intermediates $\left(\mathrm{OH} \cdot, \mathrm{O}_{2}^{-}\right)$[32], we could show that these macrophage products apparently do not play a significant role in islet-cell lysis under the conditions used in our experiments, because L-NMA completely inhibited macrophage-mediated lysis in an L-arginine reversible manner. Secondly, formation of the strong oxidant peroxynitrite and subsequent formation of $\mathrm{OH}$. by reaction of the two macrophage products $\mathrm{NO}$ and superoxide anion [33] does not seem to contribute to a great extent to islet-cell lysis, because islet cells were also lysed by the NO donor sodium nitroprusside, which does not generate oxygen radicals. These results show that indeed NO or a
Table 1. Culturing of isolated islet cells with cGMP-analogues

\begin{tabular}{lc}
\hline Compound & $\%$ islet-cell lysis \\
\hline $1 \mathrm{mmol} / 1 \mathrm{IBMX}$ & $4.7 \pm 0.9$ \\
$1 \mathrm{mmol} / \mathrm{1}$ 8-Br-cGMP + $1 \mathrm{mmol} / \mathrm{IBMX}$ & $17.8 \pm 3.9$ \\
$1 \mathrm{mmol} / \mathrm{l}$ dibut-cGMP + $1 \mathrm{mmol} / 1 \mathrm{IBMX}$ & $18.2 \pm 2.7$ \\
$1 \mathrm{mmol} / \mathrm{l}$ 8-pCPT-cGMP & $14.5 \pm 3.8$ \\
$1 \mathrm{mmol} / 1 \mathrm{dibut-cAMP}+1 \mathrm{mmol} / \mathrm{IBMX}$ & $14.9 \pm 3.7$
\end{tabular}

Islet cells were cultured for $15 \mathrm{~h}$ in the presence of cGMP-or cAMPanalogues in the absence or presence of 3-isobutyl-1-methyl-xanthine (IBMX). Subsequently, the cells were processed for electron microscopy as described in the legend of Figure 2. Values are means \pm SD of two-three individual specimens

closely-related, as yet unidentified, reactive nitrogenoxide intermediate is solely responsible for islet-cell lysis. It thus appears that islet cells are extremely sensitive to $\mathrm{NO}$, because similar or higher concentrations of sodium nitroprusside did not show any cytotoxic effect on other tissue cells such as mesangial cells [34], osteoclasts [35] or smooth muscle cells [36].

The susceptibility of islet cells towards NO is shared by both beta and non-beta cells. However, non-beta cells are located at the periphery mostly of reassociating "pseudoislets" and - under experimental in vitro conditions - are therefore the first target. In contrast, in vivo soluble mediators transported via blood will reach beta cells first [37, 38].

Interleukin-1 $\beta$ (IL-1 $\beta$ ) has been reported to induce NO production in isolated whole islets [39-42]. Although in these reports impaired insulin response was taken as an indication of cytotoxicity, lysis had not been measured. Calculating an average rat islet to consist of about 2000 cells, the nitrite concentrations measured in our co-culture system are at least 10-20 times higher compared to IL- $1 \beta$-induced nitrite concentrations of whole islets.

The mechanisms by which NO mediates cytostasis of tumour cells include intracellular loss of iron [43], inactivation and degradation of $\mathrm{Fe}-\mathrm{S}$ prosthetic groups of citric acid cycle enzyme aconitase [44], complex I and complex II of the mitochondrial electron transport chain [45] and inhibition of ribonucleotide reductase [46, 47], a ratelimiting enzyme in DNA synthesis and repair. In addition, NO-induced genotoxic effects have been found [48, 49]. Our morphological investigations show that co-incubation with activated macrophages as well as with NP results in chromatin condensation within the nuclei of isolated islet cells. First results indicate the occurrence of DNA strand breaks in islet cells as an early sign of toxicity (K.Fehsel, A.Jalowy, S.Qi, V.Burkart, B.Hartmann, H. Kolb, unpublished data).

The physiological role of NO may be to act as a signal transduction effector molecule specifically stimulating the cytosolic guanylate cyclase [27]. It has been shown that short-term incubation with NP or L-arginine indeed elevates the cGMP-concentration in isolated rat islets most probably via NO $[28,29]$. However, in our experiments incubation of islet cells with very high concentrations of various CGMP-analogues did not result in significant cell lysis, indicating that elevation of intracellular CGMP is not sufficient to trigger islet-cell death. 
In vivo administration of $\mathrm{NO}$-synthase inhibitors partially prevented the onset of hyperglycaemia in low-dose streptozotocin-treated mice, suggesting that NO formation plays an important role in this animal model of Type 1 diabetes $[50,51]$.

In conclusion, the data presented show for the first time that $\mathrm{NO}$ is toxic to islet cells in the absence of other inflammatory mediators and at concentrations which were shown to be non-lytic for other cell types [34-36]. NOmediated cytotoxicity may play a crucial role in the destruction of normal, non-transformed tissue at sites of inflammatory processes.

Acknowledgements. We gratefully acknowledge the excellent technical assistance of Ms. U.Lammersen, A.Schloemer and C. Schorn, processing of micrographs by Ms. S. Wenzel-Unger and M. Turken and manuscript typing by Ms. A. Schuster. This work was supported by a grant from the Deutsche Forschungsgemeinschaft (Ko 806/2-3 to V.K.-B.) and by the Bundesministerium für Jugend, Familie und Gesundheit and the Ministerium für Wissenschaft und Forschung des Landes Nordrhein-Westfalen.

\section{References}

1. Kolb-Bachofen V, Epstein S, Kiesel U, Kolb H (1988) Low dose streptozotocin-induced diabetes in mice. Electron microscopy reveals single-cell insulitis before diabetes onset. Diabetes 37 : 21-27

2. Lee KU, Kim MK, Amano K et al. (1988) Preferential infiltration of macrophages during early stages of insulitis in diabetesprone BB rats. Diabetes 37: 1053-1058

3. Hanenberg H, Kolb-Bachofen V, Kantwerk-Funke G, Kolb H (1989) Macrophage infiltration precedes and is prerequisite for lymphocytic insulitis of pre-diabetic BB rats. Diabetologia 32: 126-134

4. Oschilewksi M, Kiesel U, Kolb H (1986) Administration of silica prevents diabetes in BB rats. Diabetes 34: 197-199

5. Lee KU, Amano K, Yoon J (1988) Evidence for initial involvement of macrophages in development of insulitis in NOD mice. Diabetes 37: 989-991

6. Marletta MA, Yoon PS, Iyengar R, Leaf CD, Wishnok JS (1988) Macrophage oxidation of $\mathrm{L}$-arginine to nitrite and nitrate: nitric oxide is an intermediate. Biochemistry $27: 8706-8711$

7. Hibbs JB, Taintor RR, Vavrin Z, Rachlin EM (1988) Nitric oxide: a cytotoxic activated macrophage effector molecule. Biochem Biophys Res Commun 157: 87-94

8. Stuehr DJ, Gross SS, Sakuma I, Levi R, Nathan CF (1989) Activated murine macrophages secrete a metabolite of arginine with the bioactivity of endothelium-derived relaxing factor and the chemical reactivity of nitric oxide. J Exp Med 169: 1011-1020

9. James SL, Glaven J (1989) Macrophage cytotoxicity against schistosomula of Schistosoma mansoni involves argininedependent production of reactive nitrogen intermediates. J Immunol 143: 4208-4212

10. Green SJ, Meltzer MS, Hibbs JB, Nacy CA (1990) Activated macrophages destroy intracellular Leishmania major amastigotes by an L-arginine-dependent killing mechanism. J Immunol 144: $278-283$

11. Adams LB, Hibbs JB, Taintor RR, Krahenbuhl JL (1990) Microbiostatic effect of murine-activated macrophages for Toxoplasma gondii. Role for synthesis of inorganic nitrogen oxides from L-arginine. J Immunol 144: 2725-2729

12. Hibbs JB, Vavrin Z, Taintor RR (1987) L-arginine is required for expression of the activated macrophage effector mechanism causing selective metabolic inhibition in target cells. J Immunol 138: $550-565$
13. Stuehr DJ, Nathan CF (1989) Nitric oxide. A macrophage product responsible for cytostasis and respiratory inhibition of tumor target cells. J Exp Med 169: 1543-1555

14. Keller R, Geiges M, Keist R (1990) L-arginine-dependent reactive nitrogen intermediates as mediators of tumor cell killing by activated macrophages. Cancer Res 50: 1421-1425

15. Kröncke KD, Funda J, Berschick B, Kolb H, Kolb-Bachofen V (1991) Macrophage cytotoxicity towards isolated islet cells: neither lysis nor its protection by nicotinamide are beta-cell specific. Diabetologia 34: 232-238

16. Appels B, Burkart V, Kantwerk-Funke G, Funda J, KolbBachofen V, Kolb H (1989) Sponteanous cytotoxicity of macrophages against pancreatic islet cells. J Immunol 142: 3803-3808

17. Kröncke KD, Kolb-Bachofen V, Berschick B, Burkart V, Kolb H (1991) Activated macrophages kill pancreatic syngeneic islet cells via arginine-dependent nitric oxide generation. Biochem Biophys Res Commun 175: 752-758

18. Wood KS, Buga GM, Byrns RE, Ignarro LJ (1990) Vascular smooth muscle-derived relaxing factor (MDRF) and its close similarity to nitric oxide. Biochem Biophys Res Commun 170: $80-88$

19. Heinrikson RL, Meredith SC (1984) Amino acid analysis by reverse-phase high-performance liquid chromatography: precolumn derivatization with phenylisothiocyante. Anal Biochem 136: $65-74$

20. Ding AH, Nathan CF, Stuehr DJ (1988) Release of reactive nitrogen intermediates from mouse peritoneal macrophages. J Immunol 141: 2407-2412

21. McCall TB, Feelisch M, Palmer RJM, Moncada S (1991) Identification of $\mathrm{N}$-iminoethyl-L-ornithine as an irreversible inhibitor of nitric oxide synthase in phagocytic cells. Br J Pharmacol 102: 234-238

22. Lambert LE, Whitten JP, Baron BM, Cheng HC, Doherty NS, McDonald IA (1990) Nitric oxide synthesis in the CNS, endothelium and macrophages differs in its sensitivity to inhibition by arginine analogues. Life Sci 48: 69-75

23. Feelisch M, Noack EA (1987) Correlation between nitric oxide formation during degradation of organic nitrates and activation of guanylate cyclase. Eur J Pharmacol 139: 19-30

24. Leeuwenkamp OR, van Bennekom WP, van der Mark EJ, Bult A (1984) Nitroprusside, antihypertensive drug and analytical reagent; review of (photo)stability, pharmacology and analytical properties. Pharm Weekbl 6: 129-140

25. Lang K (1933) Die Rhodanbildung im Tierkörper. Biochem Z 259:243-256

26. Aird BA, Horowitz PM (1988) The differential functional stability of various forms of bovine liver rhodanese. Biochim Biophys Acta 956: 30-38

27. Ignarro LJ (1992) Haem-dependent activation of cytosolic guanylate cyclase by nitric oxide: a widespread signal transduction mechanism. Biochem Soc Trans 20: 465-469

28. Laychock SG (1981) Evidence for guanosine 3',5'-monophosphate as a putative mediator of insulin secretion from isolated rat islets. Endocrinology 108: 1197-1205

29. Laychock SG, Modica ME, Cavanaugh CT (1991) L-arginine stimulates cyclic guanosine $3^{\prime}, 5^{\prime}$-monophosphate formation in rat islets of Langerhans and RINm5F insulinoma cells: evidence for L-arginine: nitric oxide synthase. Endocrinology 129:3043-3052

30. Francis SH, Noblett BD, Todd BW, Weels JN, Corbin JD (1988) Relaxation of vascular and tracheal smooth muscle by cyclic nucleotide analogs that preferentially activate purified cGMPdependent protein kinase. Mol Pharmacol 34: 506-517

31. Iyengar R, Stuehr DJ, Marletta MA (1987) Macrophage synthesis of nitrite, nitrate and $\mathrm{N}$-nitrosamines: precursors and role of the respiratory burst. Proc Natl Acad Sci USA 84: 6369-6373

32. Malaisse WJ, Malaisse-Lagae F, Sener A, Pipeleers DG (1982) Determinations of the selective toxicity of alloxan to the pancreatic B cell. Proc Natl Acad Sci USA 79: 927-930

33. Radi R, Beckman JS, Bush KM, Freeman BA (1991) Peroxynitrite oxidation of sulfhydryls. The cytotoxic potential of superoxide and nitric oxide. J Biol Chem 266: 4244-4250 
34. Garg UC, Hassid A (1989) Inhibition of rat mesangial cell mitogenesis by nitric oxide-generating vasodilators. Am J Physiol 257: F60-F66

35. MacIntyre I, Zaidi M, Towhidul ASM et al. (1991) Osteoclastic inhibition: an action of nitric oxide not mediated by cyclic GMP. Proc Natl Acad Sci USA 88: 2936-2940

36. O'Connor KJ, Knowles RG, Patel KD (1991) Nitrovasodilators have proliferative as well as antiproliferative effects. J Cardiovasc Pharmacol 17 [Suppl 3]: S100-S103

37. Bonner-Weir S, Orci L (1982) New perspectives on the microvasculature of the islets of Langerhans in the rat. Diabetes 31: 883889

38. Samols E, Stagner JI, Ewart RB, Marks V (1988) The order of islet microvascular cellular perfusion is $B \rightarrow A \rightarrow D$ in the perfused rat pancreas. J Clin Invest 82: 350-353

39. Southern C, Schulster D, Green IC (1990) Inhibition of insulin secretion by interleukin $-1 \beta$ and tumor necrosis factor- $\alpha$ via an $\mathrm{L}$-arginine-dependent nitric oxide generating mechanism. FEBS Lett 276: 42-44

40. Welsh N, Eizirik DL, Bendtzen K, Sandler S (1991) Interleukin$1 \beta$-induced nitric oxide production in isolated rat pancreatic islets requires gene transcription and may lead to inhibition of the Krebs cycle enzyme aconitase. Endocrinology 129:3167-3173

41. Corbett JA, Lancaster JR Jr, Sweetland MA, McDaniel ML (1991) Interleukin- $1 \beta$-induced formation of EPR-detectable iron-nitrosyl complexes in islets of Langerhans. J Biol Chem 266: 21351-21354

42. Welsh N, Sandler S (1992) Interleukin-1 $\beta$ induces nitric oxide production and inhibits the activity of aconitase without decreasing glucose oxidation rates in isolated mouse pancreatic islets. Biochem Biophys Res Commun 182: 333-340

43. Hibbs JB, Taintor RR, Vavrin Z (1984) Iron depletion: possible cause of tumor cell cytotoxicity induced by activated macrophages. Biochem Biophys Res Commun 123: 716-723

44. Drapier JC, Hibbs JB (1986) Murine cytotoxic activated macrophages inhibit aconitase in tumor cells. J Clin Invest 78: 790-797
45. Granger DL, Lehninger AL (1982) Sites of inhibition of mitochondrial electron transport in macrophage-injured neoplastic cells. J Cell Biol 95: 527-535

46. Lepoivre M, Fieschi F, Coves J, Thelander L, Fontcave M (1991) Inactivation of ribonucleotide reductase by nitric oxide. Biochem Biophys Res Commun 179: 442-448

47. Kwon NS, Stuehr DJ, Nathan CF (1991) Inhibition of tumor cell ribonucleotide reductase by macrophage-derived nitric oxide. J Exp Med 174: 761-767

48. Wink DA, Kasprzak KS, Maragos CM et al. (1991) DNA deaminating ability and genotoxicity of nitric oxide and its progenitors. Science 254: 1001-1003

49. Nguyen T, Brunson D, Crespi CL, Penman BW, Wishnok JS, Tannenbaum SR (1992) DNA damage and mutation in human cells exposed to nitric oxide in vitro. Proc Natl Acad Sci USA 89: 3030-3034

50. Lukic ML, Stosic-Grujicic S, Ostojic N, Chan WL, Liew FY (1991) Inhibition of nitric oxide generation affects the induction of diabetes by streptozotocin mice. Biochem Biophys Res Commun 178: 913-920

51. Kolb H, Kiesel U, Kröncke KD, Kolb-Bachofen V (1991) Suppression of low dose streptozotocin induced diabetes in mice by administration of nitric oxide synthase inhibitor. Life Sci 49: PL213-PL217

Received: 27 May 1992

and in revised form: 8 September 1992

Prof. Dr. V. Kolb-Bachofen

Institut für Immunbiologie

Medizinische Einrichtungen

Heinrich-Heine-Universität Düsseldorf

Moorenstrasse 5

W-4000 Düsseldorf 1

FRG 